Original Research Article

\title{
A study of antinociceptive effect of venlafaxine in albino mice
}

\author{
Santhosh Ramakrishna ${ }^{1} *$, Shivashankaramurthy K. Gurusiddappa ${ }^{2}$, Kiran L. Jambulingappa ${ }^{2}$
}

${ }^{1}$ Department of Pharmacology, Shridevi Institute of Medical Sciences and Research Hospital, Tumakuru, Karnataka, India ${ }^{2}$ Department of Pharmacology, S. S. Institute of Medical Sciences and Research Hospital, Davanagere, Karnataka, India

Received: 08 November 2016 Accepted: 09 December 2016

*Correspondence to:

Dr. Santhosh Ramakrishna, Email: sansaggy@gmail.com

Copyright: (C) the author(s), publisher and licensee Medip Academy. This is an openaccess article distributed under the terms of the Creative Commons Attribution NonCommercial License, which permits unrestricted noncommercial use, distribution, and reproduction in any medium, provided the original work is properly cited.

\begin{abstract}
Background: Serotonin and norepinephrine are important neurotransmitters involved in pain inhibition in descending pain inhibitory tracts. Venlafaxine being an antidepressant exerts its mechanism mainly by inhibiting reuptake of serotonin and norepinephrine like Tramadol. The objectives were to study the antinociceptive activity of Venlafaxine and its comparison with Pethidine.

Methods: A total of 32 Swiss albino mice were divided into 4 groups with 8 animals in each group. Group 1 received normal saline as control in dose of $5 \mathrm{ml} / \mathrm{kg}$ i.p, Group 2 received Pethidine as standard in dose of $30 \mathrm{mg} / \mathrm{kg}$ s.c, Group 3 received Venlafaxine as in dose of $10 \mathrm{mg} / \mathrm{kg}$ i.p and Group 4 received Venlafaxine in dose of $22.5 \mathrm{mg} / \mathrm{kg}$. Tail flick test and hot plate test were used for evaluating antinociceptive activity. All animals were subjected to the above mentioned tests before and 30 minutes after the administration of the drugs. Results were subjected to suitable statistical analysis.

Results: The results from the above mentioned tests showed that Venlafaxine in dose of $10 \mathrm{mg} / \mathrm{kg}$ showed significant antinociceptive activity as compared to normal saline $(\mathrm{p}<0.05)$ but was not comparable to Pethidine ( $\mathrm{p}>0.05)$. Venlafaxine in dose of $22.5 \mathrm{mg} / \mathrm{kg}$ showed significant antinociceptive activity as compared to normal saline ( $\mathrm{p}<0.05$ ) and activity was comparable to Pethidine. Conclusions: Venlafaxine in both the doses showed significant antinociceptive activity in acute models of pain in animals.
\end{abstract}

Keywords: Analgesic, Antidepressant, Neurotransmitter, Pethidine, Tramadol, Venlafaxine

\section{INTRODUCTION}

Pain is the most common complaint that brings the patient to the physician and it usually signifies an underlying disease. Pain is an unpleasant sensation that can negatively affect all areas of a person's life, including comfort, thought, sleep, emotion, and normal daily activity. The pain sensation results from complex phenomena that involve physical perception as well as the emotional reaction to the perception. ${ }^{1}$

Pain is a direct response to an untoward event associated with tissue damage, such as injury, inflammation or cancer, it can also arise independently of any obvious predisposing cause (e.g. trigeminal neuralgia), or persist long after the precipitating injury has healed (e.g. phantom limb pain). It can also occur as a consequence of brain or nerve injury (e.g. following a stroke or herpes infection). ${ }^{2}$ Several transmitters are involved in pain suppression in the spinal cord, important of them are noradrenaline and serotonin. It has been known that fibres originating from periventricular nuclei and from the periaqueductal gray area send signals to dorsal horn to secrete serotonin at their endings. The serotonin in turn causes local cord neurons to secrete enkephalin as well, which is an endogenous opioid peptide. The enkephalin is believed to cause both presynaptic and postsynaptic inhibition of incoming type $\mathrm{C}$ and type A delta pain fibers where they synapse in the dorsal horns. ${ }^{3}$

It is also known that norepinephrine is also an important neurotransmitter in descending pain inhibitory tracts. Descending projections from the locus ceruleus LC give rise to the majority of noradrenergic fibres in the spinal cord, stimulation of which is associated with hyper vigilance and enhanced nociception. Direct stimulation of noradrenergic cells in the brain stem area especially in the locus ceruleus produces antinociception by releasing noradrenaline from the terminals found on superficial laminae of dorsal horn of spinal cord. It has also been 
demonstrated that Iontophoretic application of norepinephrine inhibits the activation of dorsal horn neurons by noxious stimuli, and intrathecal norepinephrine results in inhibition of nociceptive responses. ${ }^{4}$

Various drugs are available for the treatment of pain, both acute and chronic. They include opioids, nonopioid analgesics like acetaminophen and nonsteroidal antiinflammatory drugs (NSAIDs) like aspirin. Off late, drugs which were never developed initially as analgesics, like antidepressants, antiepileptics, dissociative anesthetic ketamine and local anesthetic lidocaine has shown analgesics properties. $^{5-8}$ Conventional analgesics specially NSAID's have various side effects associated with it like gastrointestinal irritation, erosion, ulceration, bleeding and even perforation, analgesic neuropathy especially when used chronically, headache, tinnitus, asthma, rashes, hyperkalemia, proteinuria etc. ${ }^{9}$ Opioids on the other hand has constipation, urinary retention, increase in intracranial tension, behavioral changes, restlessness, respiratory depression, abuse liability and narrow therapeutic range as adverse effects. ${ }^{10}$ NSAID's also inhibit platelet aggregation and increases risk of bruising and hemorrhage. ${ }^{11}$

Venlafaxine is an antidepressant drug approved for treatment of major depressive disorder; it acts mainly by inhibiting SERT (serotonin transporter) and NET (norepinephrine transporter). So it increases the synaptic concentrations of serotonin and norepinephrine, which are important neurotransmitters involved in pain modulation. Venlafaxine also bears close structural resemblance with a known analgesic Tramadol which also acts mainly by inhibiting reuptake of serotonin and norepinephrine. $^{12}$ Many antidepressants like TCA's, SSRI's and SNRI's have shown to be efficacious in clinical trials for neuropathic and other chronic pain syndromes but none have been shown to be useful in acute pain states. Since there is a considerably difference in etiopathogenesis of acute and chronic pain, treatment modalities also differs. So this study was taken to evaluate the antinociceptive effect of Venlafaxine in acute animal pain models. ${ }^{13}$

\section{Objectives}

1. To study the antinociceptive effect of Venlafaxine.

2. To compare the antinociceptive activity of Venlafaxine with the standard drug Pethidine.

\section{METHODS}

\section{Inclusion criteria}

- Swiss albino mice of either sex weighing between 20$25 \mathrm{~g}$.

- Aged 3-4 months.

- Healthy with normal behavior and activity.

\section{Exclusion criteria}

- Mice 25g and aged 4 months.

- Pregnant female mice and those that have delivered.

- Animals previously used for any other experiment.

A total of 32 animals were obtained from the animal house and were grouped randomly into 4 groups of 8 animals each, as follows. Group I- Control, Normal saline $5 \mathrm{ml} / \mathrm{kg}$ i.p., Group II- Standard, Pethidine $30 \mathrm{mg} / \mathrm{kg}$ s.c, Group III- Test drug, Venlafaxine $10 \mathrm{mg} / \mathrm{kg}$ i.p. and Group IV- Test drug, Venlafaxine $22.5 \mathrm{mg} / \mathrm{kg}$ i.p. ${ }^{14}$

The methods that were employed in this present study to find out the analgesic activity are 1) Radiant Heat/Tail Flick method 2) Thermal Heat/ Hot Plate method.

\section{1) Radiant heat method/ Tail Flick Test}

This method was done based on the description of D' Amour and Smith with the use of tail flick analgesiometer consisting of an electrically heated nicrome wire as a source of radiant heat. Albino mice of either sex weighing between $20-25 \mathrm{gm}$ were used for the test. They were divided into 4 groups of 8 animals each. The tail of the animal was shaved $3 \mathrm{~cm}$ from the root to ensure proper exposure to radiant heat. In this method, mouse tail was exposed to heated nicrome wire and the reaction time i.e. time from the exposure of tail to heated nicrome wire to the flick of the tail was noted by a stop watch. Normally the animal responds to this heat source within few seconds by flicking the tail. Mice with a reaction time of more than $6 \mathrm{~s}$ were not used in the test. The tail flick response was noted before and after 30 minutes of administration of vehicle/drugs. The cutoff time was taken as 15 seconds to avoid injury to the tail due to prolonged exposure to the tail. ${ }^{14}$

\section{2) Thermal heat method/ hot plate method}

The method followed here is in accordance with the method described originally by Woolfe and Mac Donald and later was modified by Eddy and Leimbach. Mice of either sex weighing 20-25gm were used for the test. Animals were divided into 4 groups of 8 animals each. Hot plate which is commercially available consists of an electrically heated surface with the temperature being maintained between $55^{\circ} \mathrm{C}+/-1.0^{\circ} \mathrm{C}$. Normally animals respond within 5 seconds when placed on hot plate either by licking the paw or jumping, and those animals not responding within 5 seconds were discarded from the test. Reaction time i.e. time starting from placing the animal on the hot plate to the first attempt at licking the paw or jumping was noted by a stop watch. The test was done before and after 30 minutes of administration of the drug/ vehicle. The cut off time was taken as 30 seconds to avoid damage to the paws from prolong contact with the hot plate. ${ }^{14}$ 


\section{Statistical analysis}

Observations were tabulated and a paired $\mathrm{t}$ test was applied for analysis of significance. Later results were subjected to ANOVA followed by post hoc test for inter group comparison.

\section{RESULTS}

\section{Tail Flick Test}

Table 1 shows the mean difference in reaction time between baseline values and values recorded after 30 minutes of drug administration by using paired ' $\mathrm{t}$ ' test are $0.069(\mathrm{p}=0.703, \mathrm{NS})$ for normal saline (group 1), $2.60(\mathrm{p}$ $<0.0001, \mathrm{HS})$ for Pethidine (group 2), $1.44(\mathrm{p}=0.0008, \mathrm{~S})$ for Venlafaxine $10 \mathrm{mg} / \mathrm{kg}$ (group 3) and $2.51 \quad(\mathrm{p}=$ $0.0006, \mathrm{~S}$ ) for Venlafaxine $22.5 \mathrm{mg} / \mathrm{kg}$ (group 4). The groups treated with Pethidine and Venlafaxine in doses of $10 \mathrm{mg} / \mathrm{kg}$ and $22.5 \mathrm{mg} / \mathrm{kg}$ showed a significant increase in the reaction time values after 30 minutes of administration of drugs as compared to their baseline values. Whereas the same was not observed in group 1 treated with normal saline. This shows that Pethidine and Venlafaxine in doses of $10 \mathrm{mg} / \mathrm{kg}$ and $22.5 \mathrm{mg} / \mathrm{kg}$ has significant antinociceptive activity as compared to normal saline.

Table 1: Paired t tests results expressed in terms of Mean +/-SEM.

\begin{tabular}{|c|c|c|c|c|}
\hline & $\begin{array}{l}\text { Baseline } \\
\text { reading } \\
\text { (in } \\
\text { seconds) }\end{array}$ & $\begin{array}{l}30 \\
\text { minutes } \\
\text { after } \\
\text { injection } \\
\text { (in sec.) }\end{array}$ & $\begin{array}{l}\text { Mean } \\
\text { difference }\end{array}$ & $\begin{array}{l}\text { P value, } \\
\text { significance }\end{array}$ \\
\hline $\begin{array}{l}\text { Group } \\
1\end{array}$ & $\begin{array}{l}2.00+/- \\
0.134\end{array}$ & $\begin{array}{l}2.06+/- \\
0.0466\end{array}$ & 0.069 & $0.703, \mathrm{NS}$ \\
\hline $\begin{array}{l}\text { Group } \\
2\end{array}$ & $\begin{array}{l}2.09+/- \\
0.178\end{array}$ & $\begin{array}{l}4.70+/- \\
0.207\end{array}$ & 2.60 & $<0.0001, \mathrm{HS}$ \\
\hline $\begin{array}{l}\text { Group } \\
3\end{array}$ & $\begin{array}{l}1.97+/- \\
0.124\end{array}$ & $\begin{array}{l}3.41+/- \\
0.180\end{array}$ & 1.44 & $0.0008, \mathrm{~S}$ \\
\hline $\begin{array}{l}\text { Group } \\
4\end{array}$ & $\begin{array}{l}2.14+/- \\
0.147\end{array}$ & $\begin{array}{l}4.65+/- \\
0.328\end{array}$ & 2.51 & $0.0006, \mathrm{~S}$ \\
\hline
\end{tabular}

$\mathrm{P}>0.05=$ not significant $(\mathrm{NS}), \mathrm{p}<0.05=\operatorname{significant}(\mathrm{S}), \mathrm{p}$ $<0.0001=$ significant $(\mathrm{HS})$

Table 2 shows values in Post hoc multiple comparisons wherein mean difference of reaction time of intergroup are compared. The mean difference calculated when we compared group 1 with group 2, group 1 with group 3 and group 1 with group 4 were 2.63 (p<0.0001, HS) 1.35 $(\mathrm{p}=0.0003, \mathrm{~S})$ and $2.58(\mathrm{p}=0.0001, \mathrm{~S})$ respectively. This indicates that Pethidine $30 \mathrm{mg} / \mathrm{kg}$, Venlafaxine $10 \mathrm{mg} / \mathrm{kg}$ and $22.5 \mathrm{mg} / \mathrm{kg}$ has significant antinociceptive effect as compared to normal saline. The mean differences got when we compared group 2 with group 3 and group 2 with group 4 were $1.29(\mathrm{p}=0.0018, \mathrm{~S})$ and 0.05 ( $\mathrm{p}=0.9161, \mathrm{NS}$ ) respectively. This indicates that Pethidine in dose of $30 \mathrm{mg} / \mathrm{kg}$ has significantly better antinociceptive activity when compared to Venlafaxine $10 \mathrm{mg} / \mathrm{kg}$. Since reaction time values between Pethidine $30 \mathrm{mg} / \mathrm{kg}$ and Venlafaxine $22.5 \mathrm{mg} / \mathrm{kg}$ are similar ( $\mathrm{p}$ $>0.05)$, it indicates that antinociceptive effect of Pethidine in dose of $30 \mathrm{mg} / \mathrm{kg}$ is comparable to antinociceptive effect of Venlafaxine in dose of $22.5 \mathrm{mg} / \mathrm{kg}$. Lastly when comparison was made between group 3 and group 4, mean calculated was 1.24 $(\mathrm{p}=0.0163, \mathrm{~S})$ indicating that Venlafaxine in dose of $22.5 \mathrm{mg} / \mathrm{kg}$ has a better antinociceptive effect than Venlafaxine $10 \mathrm{mg} / \mathrm{kg}$.

Table: 2 Post hoc multiple comparison tests.

\begin{tabular}{|lccl|}
\hline $\begin{array}{l}\text { Post hoc } \\
\text { multiple } \\
\text { comparison } \\
\text { tests }\end{array}$ & $\begin{array}{c}\text { Mean } \\
\text { difference }\end{array}$ & P value & Significance \\
\hline $\begin{array}{l}\text { Group 1 vs. } \\
\text { Group 2 }\end{array}$ & 2.63 & $<0.0001$ & $\mathrm{HS}$ \\
\hline $\begin{array}{l}\text { Group 1 vs. } \\
\text { Group 3 }\end{array}$ & 1.35 & 0.0003 & $\mathrm{~S}$ \\
\hline $\begin{array}{l}\text { Group 1 vs. } \\
\text { Group 4 }\end{array}$ & 2.58 & 0.0001 & $\mathrm{~S}$ \\
\hline $\begin{array}{l}\text { Group 2 vs. } \\
\text { Group 3 }\end{array}$ & 1.29 & 0.0018 & $\mathrm{~S}$ \\
\hline $\begin{array}{l}\text { Group 2 vs. } \\
\text { Group 4 }\end{array}$ & 0.05 & 0.9161 & $\mathrm{NS}$ \\
\hline $\begin{array}{l}\text { Group 3 vs. } \\
\text { Group 4 }\end{array}$ & 1.24 & 0.0163 & $\mathrm{~S}$ \\
\hline $\begin{array}{l}\text { p }>0.05=\text { not significant } \\
<0.0001=\text { significant (HS) }\end{array}$ & $\mathrm{p}<0.05=$ & significant (S), p \\
\hline
\end{tabular}

\section{Hot Plate Test}

Table 3: Paired t tests results expressed in terms of Mean +/-SEM in hot plate test.

\begin{tabular}{|lllll|}
\hline & $\begin{array}{l}\text { Baseline } \\
\text { reading } \\
\text { (in } \\
\text { seconds) }\end{array}$ & $\begin{array}{l}\text { 30min. } \\
\text { after } \\
\text { injection } \\
\text { (in sec.) }\end{array}$ & $\begin{array}{l}\text { Mean } \\
\text { difference }\end{array}$ & $\begin{array}{l}\text { P value, } \\
\text { Significance }\end{array}$ \\
\hline $\begin{array}{l}\text { Group } \\
1\end{array}$ & $\begin{array}{l}2.02+/- \\
0.15\end{array}$ & $\begin{array}{l}2.16+/- \\
0.14\end{array}$ & 0.149 & $0.489, \mathrm{NS}$ \\
\hline Group & $\begin{array}{l}1.92+/- \\
2\end{array}$ & $\begin{array}{l}9.70+/- \\
0.28\end{array}$ & 7.78 & $<0.0001, \mathrm{HS}$ \\
\hline Group & $2.04+/-$ & $3.86+/-$ & 1.82 & $<0.0001, \mathrm{HS}$ \\
3 & 0.19 & 0.08 & & $<0.0001, \mathrm{HS}$ \\
\hline $\begin{array}{l}\text { Group } \\
4\end{array}$ & $\begin{array}{l}2.19+/- \\
0.07\end{array}$ & $\begin{array}{l}8.93+/- \\
0.42\end{array}$ & 6.74 & \\
\hline $\mathrm{p}>0.05=$ & not significant (NS), p <0.05= significant (S), p \\
$<0.0001=$ & significant (HS)
\end{tabular}

The paired $\mathrm{t}$ test Result of hot plate test has been expressed as mean $+/$ - standard error of mean for baseline reaction times and reaction time after 30 minutes of drug administration in Table 3. The mean difference in reaction time between baseline values and values recorded after 30 minutes of drug administration are $0.149(\mathrm{p}=0.489, \mathrm{NS})$ for normal saline (group 1$), 7.78(\mathrm{p}$ 
$<0.0001$,HS) for Pethidine (group 2), 1.82 (p $<0.0001, \mathrm{HS}$ ) for Venlafaxine $10 \mathrm{mg} / \mathrm{kg}$ (group 3) and 6.74 (p <0.0001,HS) for Venlafaxine $22.5 \mathrm{mg} / \mathrm{kg}$ (group 4). The groups treated with Pethidine and Venlafaxine in doses of $10 \mathrm{mg} / \mathrm{kg}$ and $22.5 \mathrm{mg} / \mathrm{kg}$ showed a significant increase in the reaction time values after 30 minutes of administration of drugs as compared to their baseline values. Whereas the same was not observed in group 1 treated with normal saline. This shows that Pethidine and Venlafaxine in doses of $10 \mathrm{mg} / \mathrm{kg}$ and $22.5 \mathrm{mg} / \mathrm{kg}$ have significant antinociceptive activity as compared to normal saline.

Table 4 shows values in Post hoc multiple comparisons wherein mean difference of reaction time of intergroup are compared. The mean difference calculated when we compared group 1 with group 2, group 1 with group 3 and group 1 with group 4 were 7.52 (p 0.0080, S) 1.70 (p $<0.0001$, HS) and 6.77 ( $\mathrm{p}<0.0001$, HS) respectively. This indicates that Pethidine $30 \mathrm{mg} / \mathrm{kg}$, Venlafaxine $10 \mathrm{mg} / \mathrm{kg}$ and $22.5 \mathrm{mg} / \mathrm{kg}$ has significant antinociceptive effect as compared to normal saline. The mean differences got when we compared group 2 with group 3 and group 2 with group 4 were $5.84(\mathrm{p}<0.0001$, HS) and $0.76(\mathrm{p}=$ $0.1496, \mathrm{NS}$ ) respectively. This indicates that Pethidine in dose of $30 \mathrm{mg} / \mathrm{kg}$ has significantly better antinociceptive activity when compared to Venlafaxine $10 \mathrm{mg} / \mathrm{kg}$. Since reaction time values between Pethidine $30 \mathrm{mg} / \mathrm{kg}$ and Venlafaxine $22.5 \mathrm{mg} / \mathrm{kg}$ are similar $(\mathrm{p}>0.05)$, it indicates that antinociceptive effect of Pethidine in dose of $30 \mathrm{mg} / \mathrm{kg}$ is comparable to antinociceptive effect of Venlafaxine in dose of $22.5 \mathrm{mg} / \mathrm{kg}$. Lastly when comparison was made between group 3 and group 4, mean calculated was 5.07 ( $\mathrm{p}<0.0001$, HS) indicating that Venlafaxine in dose of $22.5 \mathrm{mg} / \mathrm{kg}$ has a better antinociceptive effect than Venlafaxine $10 \mathrm{mg} / \mathrm{kg}$.

\section{Table 4: Post hoc multiple comparison test of hot} plate test.

\begin{tabular}{|llll|}
\hline $\begin{array}{l}\text { Post hoc } \\
\text { multiple } \\
\text { comparison } \\
\text { tests }\end{array}$ & $\begin{array}{l}\text { Mean } \\
\text { difference }\end{array}$ & P value & Significance \\
\hline $\begin{array}{l}\text { Group 1 vs. } \\
\text { Group 2 }\end{array}$ & 7.52 & 0.0080 & $\mathrm{~S}$ \\
\hline $\begin{array}{l}\text { Group 1 vs. } \\
\text { Group 3 }\end{array}$ & 1.70 & $<0.0001$ & HS \\
\hline $\begin{array}{l}\text { Group 1 vs. } \\
\text { Group 4 }\end{array}$ & 6.77 & $<0.0001$ & HS \\
\hline $\begin{array}{l}\text { Group 2 vs. } \\
\text { Group 3 }\end{array}$ & 5.84 & $<0.0001$ & HS \\
\hline $\begin{array}{l}\text { Group 2 vs. } \\
\text { Group 4 }\end{array}$ & 0.76 & 0.1496 & NS \\
\hline $\begin{array}{l}\text { Group 3 vs. } \\
\text { Group 4 }\end{array}$ & 5.07 & $<0.0001$ & HS \\
\hline
\end{tabular}

$\mathrm{p}>0.05=$ not significant $(\mathrm{NS}), \mathrm{p}<0.05=$ significant $(\mathrm{S}), \mathrm{p}$ $<0.0001=$ significant $(\mathrm{HS})$

\section{DISCUSSION}

To sum it up, this study showed that Venlafaxine in doses viz., $\quad 10 \mathrm{mg} / \mathrm{kg}$ and $22.5 \mathrm{mg} / \mathrm{kg}$ has significant antinociceptive effect in tail flick test and hot plate test of acute pain models. It also showed that Venlafaxine in dose of $22.5 \mathrm{mg} / \mathrm{kg}$ has antinociceptive effect similar to Pethidine in dose of $30 \mathrm{mg} / \mathrm{kg}$. There is also a significant difference in the antinociceptive effect between Venlafaxine $10 \mathrm{mg} / \mathrm{kg}$ and $22.5 \mathrm{mg} / \mathrm{kg}$.

As described earlier, serotonin and norepinephrine play a pivotal role in natural descending inhibitory pain pathways coming from brain to posterior column of spinal cord. Tramadol, a well-known analgesic used in treating mild to moderate pain partly exerts its analgesic action by inhibiting reuptake of serotonin and norepinephrine. Apart from this, Venlafaxine and Tramadol share lot of similarities with each other like both exhibit methoxyphenyl, N, N-demethylamino and hydroxycyclohexyl groups, both are enantioselectively metabolized by cytochrome oxidase isoenzyme P450 2D6 and both yield pharmacologically active 0-desmethyl metabolites. ${ }^{15}$ So it might be possible atleast in part that analgesic activity of Venlafaxine is similar to Tramadol i.e. because of inhibition of serotonin and norepinephrine reuptake.

Another possibility comes from the study conducted by Gultekin H. The aim of this study was to evaluate the role of opioid system and nitric oxide pathway in antinociceptive action of Venlafaxine by using hot plate model in Wistar rats. This study showed that Venlafaxine when administered alone in dose of $22 \mathrm{mg} / \mathrm{kg}$ showed significant analgesic activity but N-nitro-l-arginine $(20 \mathrm{mg} / \mathrm{kg})$ and naloxone $(2 \mathrm{mg} / \mathrm{kg})$ administered alone showed no analgesic activity. When high dose of naloxone $(4 \mathrm{mg} / \mathrm{kg})$ was administered along with Venlafaxine $(22 \mathrm{mg} / \mathrm{kg})$, analgesic activity decreased significantly. ${ }^{16}$ This study shows that antinociceptive activity of Venlafaxine may be because of its action on opioid receptors like morphine or Pethidine.

Another possibility comes from the study conducted by Berrocoso et al. The aim of this study was to evaluate the possible role of serotoninergic system in antinociceptive action of Venlafaxine. In this study, analgesic effect was tested by using hot plate model using mice. ${ }^{17}$ This study showed that Venlafaxine showed a significant antinociceptive effect, and this effect was blocked by 5HT1A receptor antagonist indicating possible action of Venlafaxine on serotonin receptors in producing antinociception. These studies suggest that there might be multiple mechanism of antinociceptive action of Venlafaxine and that further studies are needed to convincingly prove its mechanism of antinociceptive action.

Thus this study though preliminary in nature shows that Venlafaxine in doses of $10 \mathrm{mg} / \mathrm{kg}$ and $22.5 \mathrm{mg} / \mathrm{kg}$ has 
significant antinociceptive effect as compared to normal saline and at dose of $22.5 \mathrm{mg} / \mathrm{kg}$, antinociceptive effect is comparable to that of standard drug Pethidine.

\section{CONCLUSION}

This study showed that Venlafaxine has antinociceptive activity in both the doses and at dose of $22.5 \mathrm{mg} / \mathrm{kg}$ is comparable to that of Pethidine. The antinociceptive effect of Venlafaxine can be attributed to its norepinephrine and serotonin reuptake inhibiting property which is shared by structurally similar opioid analgesic Tramadol, indicating the importance of serotonin and norepinephrine in pain mechanism.

Funding: No funding sources

Conflict of interest: None declared

Ethical approval: The study was approved by the Institutional Ethics Committee of JJM Medical College, Davangere, Karnataka

\section{REFERENCES}

1. Fields HL, Martin JB. Pain: Pathophysiology and Management. In: Fauci, Braunwald, Kasper, Hauser, Longo, Jameson, Loscalzo, editors. Harrison's Principles of Internal Medicine: $17^{\text {th }}$ edition. Vol 1. New Delhi: Mc Graw hill companies; 2008:81-84.

2. Rang HP, Dale MM, Ritter JM, Flower RJ. Analgesic drugs. In: Rang HP, Dale MM, Ritter JM, Flower RJ editors. Rang and Dale's Pharmacology: $6^{\text {th }}$ edition. Churchill Livingstone Elsevier; 2007:588.

3. Guyton AC, Hall JE. Somatic Sensations: II. Pain, Headache, and Thermal Sensations. In: Guyton. A.C, Hall. J.E. Editors. Textbook of Medical Physiology: 11th edition. Philadelphia: Elsevier Saunders; 2006:602.

4. Hudspith MJ, Siddall PJ, Munglani R. Physiology of Pain. Foundations of Anesthesia: second edition. Elsevier Mosby; 2006.

5. Godfrey RG. A guide to the understanding and use of tricyclic antidepressants in the overall management of fibromyalgia and other chronic pain syndromes. Arch Intern Med. 1996;156(10):1047-52.

6. Rose MA, Kam PC. Gabapentin: pharmacology and its use in pain management. Anaesthesia. 2002;57(5):451-62.

7. Hocking G, Cousins MJ. Ketamine in chronic pain management: an evidence-based review. Anesth Analg. 2003;97(6):1730-9.

8. Rowbotham MC, Davies PS, Verkempinck C, Galer BS. Lidocaine patch: double-blind controlled study of a new treatment method for post-herpetic neuralgia. Pain. 1996;65(1):39-44.
9. Furst DE, Ulrich RW, Altamirano CV. Nonsteroidal Anti-Inflammatory Drugs, Disease-Modifying Antirheumatic Drugs, Nonopioid Analgesics, and Drugs Used in Gout. In: Katzung BG, Masters SB, Trevor AJ, editors. Basic and Clinical Pharmacology: 11th edition. New Delhi: Tata Mc Graw-hill; 2009:621-642.

10. Schumacher MA, Basbaum AI, Way WL. Opioid Analgesics and Antagonists. In: Katzung BG, Masters SB, Trevor AJ, editors. Basic and Clinical Pharmacology: 11th edition. New Delhi: Tata Mc Graw-hill; 2009:531-552.

11. Grosser T, Smyth EM, Fitzgerald GA. Antiinflammatory, Antipyretic, and Analgesic Agents; Pharmacotherapy of Gout. In Brunton L.L, Chabner BA, Knollmann BC. Editors. Goodman and Gilman's the Pharmacological Basis of Therapeutics: 12TH Edition. New York: Mc Graw-Hill; 2011:959-1005.

12. Berger M, Roth B. Pharmacology of Serotonergic and Central Adrenergic Neurotransmission. In: Golan DE, Tashjian AH, Armstrong EJ, Armstrong AW. Editors. Principles of Pharmacology: the pathophysiological basis of drug therapy. 3rd edition. Philadelphia: Lippincott Williams and Wilkins, a Wolters Kluwer business; 2012.

13. Klipa D, Russeau JC. Pain and Its Management. In: Kimble. K, Anne. M, Young, Yee. L, Alldredge, Brian K, editors. Applied Therapeutics: The Clinical Use Of Drugs: ${ }^{\text {th }}$ Edition. Lippincott Williams and Wilkins; 2009:8-2.

14. Vogel HG. Analgesic, Anti-Inflammatory, and AntiPyretic Activity. In: Drug discovery and evaluation: pharmacological assays. $3^{\text {rd }}$ completely rev., updated, and enl. ed. Berlin New York: Springer; 2008:9841116.

15. Mary EL. Antidepressants as analgesics: a review of randomized controlled trials. J Psychiatry Neurosci. 2001;26(i):30-6.

16. Gultekin H, Ahmedov V. The Role of the Opiodergic system and Nitric oxide in the Analgesic Effect of Venlafaxine. The Pharmacological Society of Japan. 2006;126(2):117-21.

17. Berrocoso E, Mico JA. Role of serotonin 5-HT1A receptors in the antidepressant-like effect and the antinociceptive effect of Venlafaxine in mice. The International Journal of Neuropsychopharmacology 2009;12:61-71.

Cite this article as: Ramakrishna S, Gurusiddappa SK, Jambulingappa KL. A study of antinociceptive effect of venlafaxine in albino mice. Int J Basic Clin Pharmacol 2017;6:184-8. 